medRxiv preprint doi: https://doi.org/10.1101/2021.03.27.21253966; this version posted March 29, 2021. The copyright holder for this preprint (which was not certified by peer review) is the author/funder, who has granted medRxiv a license to display the preprint in perpetuity.

It is made available under a CC-BY 4.0 International license .

\title{
Clinical performance evaluation of SARS-CoV-2 rapid antigen testing in point of care usage in comparison to RT-qPCR
}

Isabell Wagenhäuser ${ }^{1}$; Kerstin Knies ${ }^{2}$; Vera Rauschenberger ${ }^{3}$; Michael Eisenmann ${ }^{3}$; Miriam McDonogh ${ }^{4}$ Nils Petri ${ }^{5}$; Oliver Andres $^{6}$; Sven Flemming 7 ; Micha Gawlik ${ }^{8}$; Michael Papsdorf ${ }^{9}$; Regina Taurines ${ }^{10}$; Hartmut Böhm ${ }^{11}$; Johannes Forster ${ }^{1}$; Dirk Weismann ${ }^{5}$; Benedikt Weißbrich ${ }^{2}$; Lars Dölken²; Johannes Liese ${ }^{6}$; Oliver Kurzai ${ }^{1,12}$; Ulrich Vogel ${ }^{1,3}$; Manuel Krone ${ }^{1,3,5}$

${ }^{1}$ Institute for Hygiene and Microbiology, University of Wuerzburg, Wuerzburg, Germany

${ }^{2}$ Institute for Virology and Immunobiology, University of Wuerzburg, Wuerzburg, Germany

${ }^{3}$ Infection Control Unit, University Hospital Wuerzburg, Wuerzburg, Germany

${ }^{4}$ Department of Orthopaedic Trauma, Hand, Plastic and Reconstructive Surgery, University Hospital Wuerzburg, Wuerzburg, Germany

${ }^{5}$ Department of Internal Medicine I, University Hospital Wuerzburg, Wuerzburg, Germany

${ }^{6}$ Department of Pediatrics, University Hospital Wuerzburg, Wuerzburg, Germany

${ }^{7}$ Department of General, Visceral, Transplantation, Vascular and Pediatric Surgery, University Hospital Wuerzburg, Wuerzburg, Germany

${ }^{8}$ Department of Psychiatry and Psychotherapy, University Hospital Wuerzburg, Wuerzburg, Germany

${ }^{9}$ Department of Obstetrics and Gynecology, University Hospital Wuerzburg, Wuerzburg, Germany

${ }^{10}$ Department of Child and Adolescent Psychiatry, Psychosomatics and Psychotherapy, University Hospital Wuerzburg, Wuerzburg, Germany

${ }^{11}$ Department of Oral and Maxillofacial Surgery, University Hospital Wuerzburg, Wuerzburg, Germany

${ }^{12}$ Leibniz Institute for Natural Product Research and Infection Biology - Hans-Knoell-Institute, Jena, Germany

Corresponding author: Manuel Krone, Institute for Hygiene and Microbiology, University of Wuerzburg, Josef-SchneiderStr. 2 / E1, 97080 Wuerzburg, Germany, krone_m@ukw.de, +49-931-31-88040 
medRxiv preprint doi: https://doi.org/10.1101/2021.03.27.21253966; this version posted March 29, 2021. The copyright holder for this preprint

(which was not certified by peer review) is the author/funder, who has granted medRxiv a license to display the preprint in perpetuity.

It is made available under a CC-BY 4.0 International license.

\section{Abstract \\ Background}

Antigen rapid diagnostic tests (RDT) for SARS-CoV-2 are fast, broadly available, and inexpensive. Despite this, reliable clinical performance data is sparse.

\section{Methods}

In a prospective performance evaluation study, RDT from three manufacturers (NADAL $\AA$, Panbio ${ }^{\mathrm{TM}}$, MEDsan ${ }^{\circledR}$ ) were compared to quantitative reverse transcription polymerase chain reaction (RT-qPCR) in 5068 oropharyngeal swabs for detection of SARS-CoV-2 in a hospital setting. Viral load was derived from standardized RT-qPCR Cycle threshold $\left(\mathrm{C}_{\mathrm{t}}\right)$ values. The data collection period ranged from November 12, 2020 to February 28, 2021.

\section{Findings}

Overall, sensitivity of RDT compared to RT-qPCR was $42 \cdot 57 \%$ (95\% CI $33 \cdot 38 \%-52 \cdot 31 \%$ ), and specificity $99 \cdot 68 \%$ (95\% CI 99.48\%-99.80\%). Sensitivity declined with decreasing viral load from $100 \%$ in samples with a deduced viral load of $\geq 10^{8}$ SARS-CoV-2 RNA copies per ml to $8 \cdot 82 \%$ in samples with a viral load lower than $10^{4}$ SARS-CoV-2 RNA copies per ml. No significant differences in sensitivity or specificity could be observed between the three manufacturers, or between samples with and without spike protein variant B.1.1.7. The NPV in the study cohort was $98.84 \%$; the PPV in persons with typical COVID19 symptoms was $97 \cdot 37 \%$, and $28.57 \%$ in persons without or with atypical symptoms.

\section{Interpretation}

RDT are a reliable method to diagnose SARS-CoV-2 infection in persons with high viral load. RDT are a valuable addition to RT-qPCR testing, as they reliably detect infectious persons with high viral loads before RT-qPCR results are available.

\section{Funding}

German Federal Ministry for Education and Science (BMBF), Free State of Bavaria 
medRxiv preprint doi: https://doi.org/10.1101/2021.03.27.21253966; this version posted March 29, 2021. The copyright holder for this preprint (which was not certified by peer review) is the author/funder, who has granted medRxiv a license to display the preprint in perpetuity. It is made available under a CC-BY 4.0 International license.

\section{Research in context}

Evidence before this study

We searched PubMED an MedRxiv for articles including "COVID-19", "COVID”, "SARS-CoV-2", "coronavirus" as well as "antigen detection", "rapid antigen test", "Point-of-Care test" in title or abstract, published between January 1, 2020 and February 28, 2021. The more than 150 RDT on the market at the end of February 2021 represent a huge expansion of diagnostic possibilities. ${ }^{1}$ Performance of currently available RDT is evaluated in several international studies, with heterogeneous results. Sensitivity values of RDT range from $0 \cdot 0 \%^{2}$ to $98 \cdot 3 \%^{3}$, specificity from $19 \cdot 4 \%^{4}$ to $100 \cdot 0 \%{ }^{2,5-14}$. Some of this data differs greatly from manufacturers' data. However, these previously published performance evaluation studies were conducted under laboratory conditions using frozen swabs, or in small cohorts with middle-aged participants. Comparable RDT performance data from large-scale clinical usage is missing. ${ }^{5-19}$

\section{Added value of this study}

Based on previous examinations the real life opportunities and limitations of SARS-CoV-2 RDT as an instrument of hospital infection detection and control are still unclear as well as further study results are limited in transferability to general public. Our findings show that RDT performance in daily clinical routine is reliable in persons with high viral for punctual detection and isolation of infectious persons before RT-qPCR become available. In persons with lower viral load, or in case of asymptomatic patients SARS-CoV2 detection by RDT was unsuccessful. The general sensitivity of $42.57 \%$ is too low to accept the RDT in clinical use as an alternative to RT-qPCR in diagnosis of COVID-19. Calculated specificity was 99.68\%. The results are based on a huge study cohort with more than 5000 participants including a representative ages structure with pediatric patients up to geriatric individuals, which portrays approximately the demographic structure of the local society.

\section{Implications of all the available evidence}

Due to the low general sensitivity RDT in clinical use cannot be accepted as an alternative but as an addition to RT-qPCR in SARS-CoV-2 diagnosis. The benefit of early detection of highly infectious persons has to be seen in context of the effort of testing and isolation of false positive tested persons. 
medRxiv preprint doi: https://doi.org/10.1101/2021.03.27.21253966; this version posted March 29, 2021. The copyright holder for this preprint

(which was not certified by peer review) is the author/funder, who has granted medRxiv a license to display the preprint in perpetuity.

It is made available under a CC-BY 4.0 International license.

\section{Introduction}

For more than a year, the COVID-19 pandemic has been a worldwide public health challenge. As well as contact tracing, contact reduction, quarantine, ${ }^{20}$ and vaccination, ${ }^{21}$ the early testing und detection of infectious persons is key in mitigating the spread of disease. ${ }^{22}$

Due to its high sensitivity and specificity, quantitative reverse transcription polymerase chain reaction (RT-qPCR) has served as the gold standard in diagnosing SARS-CoV-2 since the beginning of the pandemic. However, because these tests require a diagnostic laboratory and more than an hour to complete, they are quite costly, and their availability is limited. ${ }^{23}$

Antigen rapid diagnostic tests (RDT), technically carried out as lateral flow enzyme-linked immunosorbent assays, have become a widely used alternative to RT-qPCR in SARS-CoV-2 diagnostics. ${ }^{24}$ RDT persuade through their point-of-care feasibility, short analysis time, and affordability. ${ }^{25}$

This prospective performance evaluation study compares the accuracy of RDT in comparison to RT-qPCR in daily clinical routine, with a main emphasis on sensitivity in highly infectious individuals and specificity in broad screening use. 
medRxiv preprint doi: https://doi.org/10.1101/2021.03.27.21253966; this version posted March 29, 2021. The copyright holder for this preprint (which was not certified by peer review) is the author/funder, who has granted medRxiv a license to display the preprint in perpetuity.

It is made available under a CC-BY 4.0 International license.

\section{Methods}

\section{Study setting}

The study was performed in a 1438 -bed tertiary care hospital in the district of Lower Franconia, Bavaria, Germany. Data collection period ranged from November 12, 2020 to February 28, 2021.

RDT and RT-qPCR SARS-CoV-2 testing was carried out in tandem in key situations to prevent SARS-CoV-2 outbreaks in the hospital. Patients were tested on admission to the medical, pediatric, child, and adolescent psychiatric wards, the surgical emergency department, as well as the delivery room. During the study period, usage of RDT on admission was extended to all other clinical departments of the hospital. Patients and persons accompanying underage patients were tested equally. Employees were tested in case of respiratory symptoms, and after close contacts to SARS-CoV-2 positive persons.

SARS-CoV-2 samples were collected with oropharyngeal swabs for RDT and RT-qPCR by trained medical staff. We did not use nasopharyngeal swabs as they (i) were perceived as being more unpleasant compared to oropharyngeal swabs, (ii) have been associated with serious complications, ${ }^{26}$ and (iii) do not provide advantage with regard to viral load at sampling site. ${ }^{27}$

Data was collected during the second wave of the COVID-19 pandemic in Germany. ${ }^{28}$ In the hospital's catchment area of Lower Franconia, the average weekly incidence during the study period was 119.21 per 100000 inhabitants. The maximum of daily new infections was reported on December 23, 2020. Due to a stricter lockdown, case numbers declined in January 2021. . $^{29} 30$

\section{Data collection}

RDT, RT-qPCR results, and demographic data were documented in the local hospital information system (HIS) SAP ERP 6.0 (SAP, Walldorf, Germany). Persons were categorized by symptoms into patients with typical COVID19 symptoms according to comparable COVID-19 case definition of the CDC $^{31}$ and the ECDC ${ }^{32}$ (e.g. fever, dry cough, shortness of breath, new olfactory or taste disorder), and persons without or with atypical symptoms which could be attributed to COVID-19 (e.g. deterioration of general condition, falls, diarrhea). Secondary infections caused by persons tested false negative by RDT were detected using a search of the hospitals' infection control database.

\section{Antigen rapid diagnostic tests (RDT)}

RDT from three manufacturers were selected by manufacturers' specifications and availability out of 23 products listed by the German Federal Institute for Drugs and Medical Devices in October 2020: ${ }^{33}$

(I) NADAL® COVID-19 Ag Test (Nal von Minden GmbH, Regensburg, Germany)

(II) PANBIO ${ }^{\text {TM }}$ COVID-19 Ag Rapid Test (Abbott Laboratories, Abbott Park IL, USA)

\section{(III) MEDsan® SARS-Cov-2 Antigen Rapid Test (MEDsan GmbH, Hamburg, Germany)}

All RDT included in the study target the nucleoprotein antigen of SARS-CoV-2 according to the test manuals. Sensitivities of the RDT are said to range from 92.5\% (MEDsan ${ }^{\circledR}$, no Cycle threshold $\left(\mathrm{C}_{\mathrm{t}}\right)$ value specified) over 93.3\% (PANBIO ${ }^{\mathrm{TM}}$, no $\mathrm{C}_{\mathrm{t}}$ specified) to $97 \cdot 6 \%$ (NADAL ${ }^{\circledR}, \mathrm{C}_{\mathrm{t}}$ value 20-30). Specificities are stated as $99.4 \%$ (PANBIO $\left.{ }^{\mathrm{TM}}\right)$, 99.8\% (MEDsan $\left.{ }^{\circledR}\right)$, or $>99.9 \%$ (NADAL $\left.\AA\right)$.

The PANBIO ${ }^{\text {TM }}$ RDT has been evaluated in several studies, ${ }^{5-16,19}$ and reported sensitivity values range from $44 \cdot 6 \%{ }^{13}$ to $91.7 \%{ }^{7}$. The specificity was continuously in the range of $98.9 \%{ }^{7}$ to $100 \% .^{6,8,9,14}$ Three small laboratory or cohort studies are published on NADAL ${ }^{16-18}$ Overall sensitivity ranged between $24 \cdot 3 \%{ }^{17}$ and $73 \cdot 1 \%{ }^{18}$, and test specificity estimated at more than $99 \% .{ }^{16-18}$ MEDsan ${ }^{\circledR}$ RDT has so far only been assessed in a preprint analysis, with a sensitivity of $45.8 \%$, and a specificity of $97.0 \% .{ }^{13}$ This data differs considerably from that provided by the manufacturer.

Two of the three tests (NADAL ${ }^{\circledR}$ and MEDsan $\left.{ }^{\circledR}\right)$ were approved for use on oropharyngeal swabs. The PANBIOTM RDT is approved for nasopharyngeal swabs only but was used in oropharyngeal swabs in comparison to RT-qPCR for this study. The chosen RDT were distributed to clinical sites depending on availability. All swabs were taken oropharyngeally and processed according to manufacturers' instructions. 
In case of more than one documented RDT per person per day, only the first RDT was included in the study. RDT on test persons with a recent COVID-19 infection and subsequent deisolation were excluded. This category of persons is likely no longer infectious despite persistent RT-qPCR positivity. ${ }^{34}$

\section{Quantitative reverse transcription polymerase chain reaction (RT-qPCR)}

Primary RT-qPCR was carried out in the hospital's virological diagnostic laboratory using different RT-qPCR methods, performed according to the manufacturers' instructions. Viral load was determined by retesting all samples to ascertain standardized $C_{t}$ values on MagNA Pure 96 (nucleic acid purification) and the 7500 Real-Time PCR System using FTD SARS-CoV-2 Assay. The following formula was used to calculate viral load of the sample:

$$
\operatorname{ViralLoad}(\text { Sample })=\operatorname{ViralLoad}\left(S_{1}\right) \times\left(c_{t}\left(S_{1}\right)-C_{t}\left(S_{2}\right) \sqrt{\frac{\operatorname{ViralLoad}\left(S_{2}\right)}{\operatorname{ViralLoad}\left(S_{1}\right)}}\right)^{\left(C_{t}\left(S_{1}\right)-C_{t}(\text { Sample })\right)}
$$

Standards of $10^{6}\left(\mathrm{~S}_{1}\right)$ and $10^{7}\left(\mathrm{~S}_{2}\right)$ SARS-CoV-2 RNA copies per ml were tested three times and resulted in average $\mathrm{C}_{\mathrm{t}}$ values of $21.3\left(\mathrm{~S}_{1}\right)$ and $18 \cdot 2\left(\mathrm{~S}_{2}\right)$. In two samples with high $\mathrm{C}_{\mathrm{t}}$ values $(34.3$ and 37.2$)$ on NeuMoDx ${ }^{\mathrm{TM}}$, not enough material was available for retesting, so they were excluded from viral load analysis.

Starting on February 3, 2021, all new RT-qPCR positive samples with sufficient viral load underwent melting curve analysis to detect mutation N501Y, followed by a $\Delta 69-70$ deletion PCR to detect variant B.1.1.7. If the mutation $\mathrm{N} 501 \mathrm{Y}$ without a $\Delta 69-70$ deletion was detected, genome sequencing was performed to detect other variants of concern.

\section{Ethical approval}

The Ethics committee of the University of Wuerzburg waived the need to formally apply for ethical clearance due to the study design (File No. 20210112 01).

\section{Statistics}

Data analysis was performed using Excel® 2019 (Microsoft, Redmond WA, USA), SPSS Statistics 26 (IBM, Armonk NY, USA), and GraphPad Prism (GraphPad Software, San Diego CA, USA).

The Wilson/Brown method was used for confidence interval calculation. ${ }^{35}$ Test performance regarding spike protein variants and symptomatology was compared using Fisher's exact test. Test performance between manufacturers was compared using Chi-squared test. Viral load between RDT positive and negative persons, as well as between symptomatic, asymptomatic, or atypically symptomatic persons were compared using Mann-Whitney U test. Influence of age on test sensitivity and specificity was analyzed by binary logistic regression. A Pearson correlation coefficient was used to assess the correlation between age and viral load. The two-tailed significance level $\alpha$ was set to $0 \cdot 05$.

\section{Role of the funding source}

This study was initiated by the investigators. The sponsoring institutions had no function in study design, data collection, analysis, and interpretation of data as well as in writing of the manuscript. All authors had unlimited access to all data. The first and the corresponding author had final responsibility for the decision to submit for publication. 
medRxiv preprint doi: https://doi.org/10.1101/2021.03.27.21253966; this version posted March 29, 2021. The copyright holder for this preprint (which was not certified by peer review) is the author/funder, who has granted medRxiv a license to display the preprint in perpetuity.

It is made available under a CC-BY 4.0 International license.

\section{Results}

\section{Test enrollment}

Between November 12, 2020 and February 28, 2021, a total of 5171 parallel RDT and RT-qPCR were carried out. 96 tests were excluded as only the first RDT of each person each day was included. Seven tests were excluded because of persistently positive RT-qPCR results. 5068 RDT carried out on 4623 individuals were enrolled and included in the study. NADAL $®$ was used in $810(15 \cdot 9 \%)$, PANBIO $^{\mathrm{TM}}$ in $1030(20 \cdot 36 \%)$ and MEDsan® in 3228 $(63.7 \%)$ tests (Fig. 1).

Fig. 1: Enrollment of antigen rapid diagnostic test (RDT) results in the study

\section{Study population}

The tested persons were between 0 and 100 years old (median age: 43 years). 2677 tests $(52.82 \%)$ were performed on female, $2390(47 \cdot 16 \%)$ on male persons. One test was performed on a person assigned to a diverse gender $(0 \cdot 02 \%) .4115$ tests were performed on patients (81.20\%), 615 on accompanying persons (12.13\%), and 338 on staff $(6 \cdot 67 \%)$.

Fig. 2 compares the demographics of the study population to the general population. $22 \cdot 10 \%$ of all tested persons were younger than 20 years, $9 \cdot 41 \%$ were 80 years, or older.

Fig. 2: Demographics of the study population compared to the general population of the hospital's catchment area

\section{Performance of RDT in comparison to RT-qPCR}

Out of 5,056 analyzed RDT/RT-qPCR pairs, 101 samples $(2 \cdot 00 \%)$ tested positive by RT-qPCR, $59(1 \cdot 17 \%)$ by RDT. Thus, 43 samples $(0.85 \%)$ were assessed true positive, 4939 true negative $(97.69 \%)$, 16 false positive $(0 \cdot 32 \%)$, and 58 false negative $(1 \cdot 15 \%)$. Twelve RDT samples were excluded from performance analysis because of their invalid RDT result (negative in the positive control, or interfering lines, 4 NADAL $\AA$, 1 PANBIO ${ }^{\mathrm{TM}}, 7$ MEDsan®, Fig. 1). Of these, three were RT-qPCR positive.

The overall sensitivity of RDT was $42 \cdot 57 \%$ (95\% CI 33.38\%-52.31\%), the specificity $99 \cdot 68 \%$ (95\%CI 99.48\%99.80\%). The positive predictive value (PPV) was $72.88 \%$ (95\% CI 60.40\%-82.56\%), and the negative predictive value (NPV) $98 \cdot 84 \%$ (95\% CI 98.50\%-99.10\%).

\section{Comparison of manufacturers}

Sensitivity ranged from $36 \cdot 51 \%(23 / 63,95 \%$ CI, $25 \cdot 72 \%-48 \cdot 18 \%)$ for MEDsan® over $46 \cdot 67 \%(7 / 15,95 \%$ CI, $24 \cdot 81 \%$ to $69 \cdot 88 \%$ ) for PANBIO ${ }^{\mathrm{TM}}$ to $56 \cdot 52 \%(13 / 23,95 \%$ CI $36 \cdot 81 \%-74 \cdot 37 \%)$ for NADAL $囚$. Specificity ranged from $99 \cdot 61 \%$ (1 010/1 014, 95\% CI 98.99\%-99.85\%) for PANBIO ${ }^{\text {Tм }}$ over 99.62\% (3 146/3 158, 95\% CI 99.34\%99.78\%) for MEDsan® to $100.00 \%$ (783/783, 95\% CI 99.51\%-100.00\%) for NADAL®. Differences in sensitivity $(\mathrm{p}=0 \cdot 24)$, and specificity $(\mathrm{p}=0 \cdot 22)$ were not significant (Fehler! Verweisquelle konnte nicht gefunden werden.).

Fig. 3: Antigen rapid diagnostic test performance compared to quantitative reverse transcription polymerase chain reaction by manufacturer

\section{Relation to viral load}

$\mathrm{C}_{\mathrm{t}}$ values in 99 samples tested on the reference system ranged from $11 \cdot 01$ to $35 \cdot 25$ (mean 24.22; SD 5.97), calculated viral loads from $3 \cdot 16 \times 10^{1}$ to $2 \cdot 09 \times 10^{9}$ SARS-CoV-2 RNA copies per ml. Viral loads in RDT positive persons (median viral load, $2.73 \times 10^{6}$ copies per ml; range, $1.44 \times 10^{2}$ to $2.09 \times 10^{9}$ ) were significantly higher compared to RDT negative persons (median viral load, $6 \cdot 23 \times 10^{3}$ copies per ml; range, $3 \cdot 16 \times 10^{1}$ to $2 \cdot 77 \times 10^{7}$, $\mathrm{p}<0 \cdot 0001$, Fehler! Verweisquelle konnte nicht gefunden werden.).

Fig. 4: Antigen rapid diagnostic test result in comparison to viral load

Sensitivity was $100 \%$ in samples with a viral load of $\geq 10^{8}$ SARS-CoV-2 RNA copies per ml (8/8, 95\% CI $67 \cdot 56 \%-$ $100.00 \%), 76 \cdot 92 \%$ in samples with a viral load: $10^{6}$ to $10^{8}$ copies per $\mathrm{ml}(20 / 26,95 \%$ CI $57 \cdot 95 \%-88 \cdot 97 \%), 38 \cdot 71 \%$ in samples with a viral load of $10^{4}$ to $10^{6}$ copies per ml (12/31, 95\% CI $\left.23 \cdot 73 \%-56 \cdot 18 \%\right)$, and $8 \cdot 82 \%(3 / 34,95 \%$ CI $3.05 \%-22 \cdot 96 \%$ ) in samples with a viral load $<10^{4}$ copies per ml (Fig. 5).

Fig. 5: Sensitivity of antigen rapid diagnostic testing in relation to viral load 
medRxiv preprint doi: https://doi.org/10.1101/2021.03.27.21253966; this version posted March 29, 2021. The copyright holder for this preprint (which was not certified by peer review) is the author/funder, who has granted medRxiv a license to display the preprint in perpetuity.

It is made available under a CC-BY 4.0 International license .

\section{Relation to spike protein variant}

Twenty-three samples were analyzed for a N501Y mutation: ten of these (43.47\%) showed a mutation as well as a $\triangle 69-70$ deletion compatible with variant B.1.1.7. No other spike protein variants were found. RDT sensitivity $(40 \cdot 00 \%, 4 / 10,95 \%$ CI $16 \cdot 82 \%-68.73 \%)$ did not differ from wild type samples, and samples not analyzed for N501Y mutation $(\mathrm{p}=1 \cdot 00)$.

\section{Relation to age}

RDT sensitivity was lowest in persons $<20$ years $(14 \cdot 29 \%, 1 / 7,95 \%$ CI $0 \cdot 73 \%-51 \cdot 31 \%)$, and increased with age to $59.26 \%(16 / 27,95 \%$ CI $40 \cdot 73 \%-75.49 \%)$ in persons $\geq 80$ years. Sensitivity correlated positively with age $(\mathrm{p}=0 \cdot 02)$ as did logarithmical viral load (Correlation coefficient $\rho=0 \cdot 235 ; \mathrm{p}=0 \cdot 02$ ). There was no significant influence of age on test specificity $(\rho=0 \cdot 010 ; p=0 \cdot 03)$.

\section{Relation to symptoms}

Twenty-five of 101 RT-qPCR positive tests $(24.75 \%)$ were performed on asymptomatic persons and persons with atypical symptoms which may be attributed to COVID-19, and $76(75 \cdot 24 \%)$ on persons with typical COVID-19 symptoms. Sensitivity $(24.00 \%, 6 / 25,95 \%$ CI $11 \cdot 50 \%-43 \cdot 43 \%)$, and PPV $(28 \cdot 57 \%, 6 / 21$, 95\% CI $13 \cdot 81 \%-$ 49.96\%) were significantly lower in asymptomatic and atypically symptomatic persons compared to persons with typical COVID-19 symptoms. These showed a sensitivity of $48 \cdot 68 \%(37 / 76,95 \%$ CI $37 \cdot 78 \%-59 \cdot 71 \%$, p=0.04), and a PPV of $97 \cdot 37 \%(37 / 38,95 \%$ CI $86 \cdot 51 \%-99 \cdot 87 \%, \mathrm{p}<0 \cdot 0001)$. This is in line with higher viral loads in typically symptomatic persons (median: $2 \cdot 10 \times 10^{5}$ SARS-CoV-2 RNA copies per ml) compared to asymptomatic or atypically symptomatic persons (median: $9 \cdot 63 \times 10^{3}$ copies per $\mathrm{ml}, \mathrm{p}=0 \cdot 22$ ).

\section{Secondary infections}

One secondary infection was detected a patient who was placed in a two-bed room with an asymptomatic patient after a false negative RDT result (viral load: $6 \cdot 70 \times 10^{6}$ SARS-CoV-2 RNA copies per ml). 
medRxiv preprint doi: https://doi.org/10.1101/2021.03.27.21253966; this version posted March 29, 2021. The copyright holder for this preprint (which was not certified by peer review) is the author/funder, who has granted medRxiv a license to display the preprint in perpetuity.

It is made available under a CC-BY 4.0 International license.

\section{Discussion}

Our study proves that combining RDT with an RT-qPCR-based test strategy is useful for early detection of persons with high viral load to quickly identify und isolate highly infectious persons before RT-qPCR results are available.

The overall RDT sensitivity of $42.6 \%$ differs dramatically from the manufacturers' information of all three RDT, and is comparable with the results of other publications. ${ }^{13,14,17,19}$ Specificity for all used RDT was above 99.6\%, which is comparable to manufacturers' data as well as performance in other studies. ${ }^{6-10,13-17,19}$ Our data confirms that sensitivity of RDT strongly depends on viral load. Although sensitivity is less than $10 \%$ in samples with a low viral load, it reaches $100 \%$ with a viral load of more than $10^{8}$ SARS-CoV-2 RNA copies per ml. As the latter defines potential super-spreaders, it is crucial to identify those individuals as quickly as possible to prevent hospital outbreaks. ${ }^{36}$ The low sensitivity of RDT in persons with low viral loads means these tests must be combined with RT-qPCR. Persons may have a low viral load, and not be infectious, at the end of a previously undiagnosed COVID19 infection. This load decreases further. ${ }^{34}$ In contrast, viral load at the beginning of a SARS-CoV-2 infection is low, and rapidly increases after the test is performed. Unless these individuals are identified by a parallel RT-qPCR, a false negative RDT may cause and fuel outbreaks. ${ }^{37}$ Additionally, incorrect swabbing may strongly decrease invitro viral load in the sample and falsely suggest a lower viral load. ${ }^{38}$ Because they are more susceptible to false negatives with low viral loads, RDT are more prone to sampling problems.

As the PPV is highly dependent on prevalence in the tested population, false positive RDT results do not pose a relevant threat in populations with high prevalence. However, broad use of RDT in asymptomatic individuals in a low prevalence setting may result in a large number of false positive results.

No significant differences in RDT sensitivity or specificity were found between the three products tested. This is especially important because while NADAL ${ }^{\circledR}$ and MEDsan ${ }^{\circledR}$ RDT are approved for both nasopharyngeal and oropharyngeal specimens, PANBIO ${ }^{\mathrm{TM}}$ is only approved for nasopharyngeal specimens. Our data indicates that PANBIO $^{\mathrm{TM}}$ is comparable the other two RDT in oropharyngeal specimen sampling, which may be better tolerated by patients.

RT-qPCR was positive in three of twelve persons with a documented invalid RDT result. This suggests that persons with atypical lines and thus invalid RDT results should be treated as RDT positive until RT-qPCR results are available.

No differences were found in RDT performance regarding spike protein variant B.1.1.7. This is significant because the proportion of this variant is dramatically increasing worldwide. ${ }^{39}$

Sensitivity was lowest in persons younger than 20 years, as was viral load determined by RT-qPCR. This may represent in-vivo viral load and indicate decreased infectiousness. It may also be explained by the fact that correct sampling procedure in children is more challenging than in adults. This must be considered when RDT is used in children.

Our study has several limitations. For each participant was assessed only by one of the three chosen RDT, and therefore different RDT only compared indirectly. Moreover, the distribution of the three RDT was inhomogeneous throughout the different clinical departments. Each of these also has an individual patient structure. Despite this, our data represents in vivo experience with RDTs in a large cohort. The low incidence of SARS-CoV-2 in our study setting limits the number of RT-qPCR positive persons in the study but reflects a realistic scenario of present and future RDT use. The performance of RDTs in other spike protein variants cannot be assessed as they were not determined in the study population. Given the targets of the assays, however, spike protein mutations are unlikely to affect RDT-detection. 
medRxiv preprint doi: https://doi.org/10.1101/2021.03.27.21253966; this version posted March 29, 2021. The copyright holder for this preprint (which was not certified by peer review) is the author/funder, who has granted medRxiv a license to display the preprint in perpetuity.

It is made available under a CC-BY 4.0 International license .

\section{Conclusion}

RDT are a reliable diagnostic tool to quickly detect persons with a high SARS-CoV-2 viral load. Usage of RDT can help to detect and isolate potential super-spreaders before RT-qPCR results are available, especially for persons entering the hospital. RDT can also help to accelerate treatment of critically ill patients by ruling out high infectiousness. However, all used RDT were unsuccessful in detecting persons with lower viral load. This problem may be aggravated by inadequate sampling, and can result in failure to detect patients in an early stage of infection (i.e. with low but rapidly increasing viral loads). Thus, sensitivity of RDT is too low to accept its clinical use as an alternative to RT-qPCR in diagnosing COVID-19 when RT-qPCR is available. In a low incidence scenario, the benefit of detecting highly infectious persons by RDT has to be weighed against the effort of testing and isolating falsely positive tested persons taking into account the SARS-CoV-2 prevalence in the population. 
medRxiv preprint doi: https://doi.org/10.1101/2021.03.27.21253966; this version posted March 29, 2021. The copyright holder for this preprint (which was not certified by peer review) is the author/funder, who has granted medRxiv a license to display the preprint in perpetuity.

It is made available under a CC-BY 4.0 International license .

\section{Author contributions}

Ms Wagenhäuser and Dr Krone had full access to all of the data in the study and take responsibility for the integrity of the data and the accuracy of the data analysis.

Concept and design: Andres, Forster, Weismann, Weißbrich, Dölken, Liese, Kurzai, Vogel, Krone.

RT-qPCR testing as well as a standardized $\mathrm{C}_{\mathrm{t}}$ quantification: Knies, Weißbrich.

RDT use and documentation instruction in different departments: Rauschenberger, Eisenmann, Andres, Weismann, Flemming, Gawlik, Papsdorf, Taurines, Böhm, Krone.

User support: Rauschenberger, Eisenmann, Vogel, Krone.

Collection of clinical data from patient's files: Wagenhäuser, Rauschenberger, Eisenman, McDonogh, Petri, Krone.

Statistical analysis: Wagenhäuser, Krone.

Obtained funding: Kurzai, Vogel.

First draft of the manuscript: Wagenhäuser, Krone.

Reviewing and modifying the manuscript and approving its final version: Knies, Rauschenberger, Eisenmann, McDonogh, Petri, Andres, Flemming, Gawlik, Papsdorf, Taurines, Böhm, Forster, Weismann, Weißbrich, Dölken, Liese, Kurzai, Vogel.

\section{Declaration of competing interest}

None of the authors has any conflict of interest.

\section{Funding}

This study was funded by the German Federal Ministry for Education and Science (BMBF) within the program InfectControl (project COVMon, grant-No 03COV26A) and via a grant provided to the University Hospital of Wuerzburg by the Network University Medicine on COVID-19 (B-FAST, grant-No 01KX2021) as well as by the Free State of Bavaria with COVID-research funds provided to the University of Wuerzburg, Germany.

Nils Petri is supported by the German Research Foundation (DFG) funded scholarship UNION CVD.

\section{Data sharing statement}

Individual participant data that underlie the results reported in this article, after de-identification (text, tables, figures, and appendices) as well as the study protocol, statistical analysis plan, and analytic code is made available to researchers who provide a methodologically sound proposal to achieve aims in the approved proposal on request to the corresponding author.

\section{Additional contributions}

We thank all hospital staff for conducting RDT testing and documenting test results and all laboratory staff in the virological diagnostic laboratory for performing RT-qPCR testing. We thank accounting department from medical controlling for SAP support. 
medRxiv preprint doi: https://doi.org/10.1101/2021.03.27.21253966; this version posted March 29, 2021. The copyright holder for this preprint (which was not certified by peer review) is the author/funder, who has granted medRxiv a license to display the preprint in perpetuity.

It is made available under a CC-BY 4.0 International license .

\section{References}

1. Foundation of Innovative New Diagnostics: SARS-CoV-2 diagnostic pipeline, https://www.finddx.org/covid-

\%2019/pipeline/?avance=all\&type=Rapid+diagnostic+tests\&test target=Antigen\&status=all\&sect\%20io $\mathrm{n}=$ show-all\&action=default (Accessed 9 March 2021). 2021.

2. Weitzel T, Legarraga $P$, Iruretagoyena $M$, et al. Comparative evaluation of four rapid SARSCoV-2 antigen detection tests using universal transport medium. Travel Med Infect Dis 2020; 39: 101942.

3. Chaimayo C, Kaewnaphan B, Tanlieng N, et al. Rapid SARS-CoV-2 antigen detection assay in comparison with real-time RT-PCR assay for laboratory diagnosis of COVID-19 in Thailand. Virol $J$ 2020; 17(1): 177.

4. Schildgen V, Demuth S, Lüsebrink J, Schildgen O. Limits and opportunities of SARS-CoV-2 antigen rapid tests - an experience based perspective. medRxiv 2020: 2020.09.22.20199372.

5. Agullo V, Fernandez-Gonzalez M, Ortiz de la Tabla V, et al. Evaluation of the rapid antigen test Panbio COVID-19 in saliva and nasal swabs in a population-based point-of-care study. J Infect 2020.

6. Albert E, Torres I, Bueno F, et al. Field evaluation of a rapid antigen test (Panbio COVID-19 Ag Rapid Test Device) for COVID-19 diagnosis in primary healthcare centres. Clin Microbiol Infect 2020.

7. Alemany A, Baro B, Ouchi D, et al. Analytical and clinical performance of the panbio COVID-19 antigen-detecting rapid diagnostic test. J Infect 2021.

8. $\quad$ Berger A, Ngo Nsoga MT, Perez-Rodriguez FJ, et al. Diagnostic accuracy of two commercial SARS-CoV-2 Antigen-detecting rapid tests at the point of care in community-based testing centers. medRxiv 2020: 2020.11.20.20235341.

9. Gremmels H, Winkel BMF, Schuurman R, et al. Real-life validation of the Panbio COVID-19 antigen rapid test (Abbott) in community-dwelling subjects with symptoms of potential SARS-CoV-2 infection. EClinicalMedicine 2021; 31: 100677.

10. Krüger LJ, Gaeddert M, Tobian F, et al. Evaluation of the accuracy and ease-of-use of Abbott PanBio - A WHO emergency use listed, rapid, antigen-detecting point-of-care diagnostic test for SARSCoV-2. medRxiv 2020: 2020.11.27.20239699.

11. Lanser L, Bellmann-Weiler R, Öttl KW, et al. Evaluating the clinical utility and sensitivity of SARS-CoV-2 antigen testing in relation to RT-PCR Ct values. Infection 2020: 1-3.

12. Linares $M$, Perez-Tanoira $R$, Carrero $A$, et al. Panbio antigen rapid test is reliable to diagnose SARS-CoV-2 infection in the first 7 days after the onset of symptoms. J Clin Virol 2020; 133: 104659. 13. Olearo F, Nörz D, Heinrich F, et al. Handling and accuracy of four rapid antigen tests for the diagnosis of SARS-CoV-2 compared to RT-qPCR. medRxiv 2020: 2020.12.05.20244673.

14. Torres I, Poujois S, Albert E, Colomina J, Navarro D. Evaluation of a rapid antigen test (Panbio COVID-19 Ag rapid test device) for SARS-CoV-2 detection in asymptomatic close contacts of COVID19 patients. Clin Microbiol Infect 2021.

15. Abdulrahman A, Mustafa F, AIAwadhi Al, Alansari Q, AIAlawi B, AIQahtani M. Comparison of SARS-COV-2 nasal antigen test to nasopharyngeal RT-PCR in mildly symptomatic patients. medRxiv 2020: 2020.11.10.20228973.

16. Corman VMH, V. C.; Bleicker, T.; Schmidt, M. L.; Mühlemann, B.; Zuchowski, M.; Jó Lei, W. K.; Tscheak, P.; Möncke-Buchner, E.; Müller, M. A.; Krumbholz, A.; Drexler, J. F.; Drosten, C. Comparison of seven commercial SARS-CoV-2 rapid Point-of-Care Antigen tests. 2020.

17. Kohmer N, Toptan T, Pallas C, et al. The Comparative Clinical Performance of Four SARS-CoV2 Rapid Antigen Tests and Their Correlation to Infectivity In Vitro. J Clin Med 2021; 10(2).

18. Stromer A, Rose R, Schafer M, et al. Performance of a Point-of-Care Test for the Rapid Detection of SARS-CoV-2 Antigen. Microorganisms 2020; 9(1).

19. Villaverde S, Dominguez-Rodriguez S, Sabrido G, et al. Diagnostic Accuracy of the Panbio SARS-CoV-2 Antigen Rapid Test Compared with Rt-Pcr Testing of Nasopharyngeal Samples in the Pediatric Population. J Pediatr 2021.

20. Nussbaumer-Streit B, Mayr V, Dobrescu AI, et al. Quarantine alone or in combination with other public health measures to control COVID-19: a rapid review. Cochrane Database Syst Rev 2020; 4(4): Cd013574. 
medRxiv preprint doi: https://doi.org/10.1101/2021.03.27.21253966; this version posted March 29, 2021. The copyright holder for this preprint (which was not certified by peer review) is the author/funder, who has granted medRxiv a license to display the preprint in perpetuity.

It is made available under a CC-BY 4.0 International license .

21. Mello MM, Silverman RD, Omer SB. Ensuring Uptake of Vaccines against SARS-CoV-2. New England Journal of Medicine 2020; 383(14): 1296-9.

22. Krüger S, Leskien M, Schuller P, et al. Performance and feasibility of universal PCR admission screening for SARS-CoV-2 in a German tertiary care hospital. J Med Virol 2021.

23. Corman VM, Landt O, Kaiser M, et al. Detection of 2019 novel coronavirus (2019-nCoV) by realtime RT-PCR. Euro Surveill 2020; 25(3).

24. Loeffelholz MJ, Tang YW. Laboratory diagnosis of emerging human coronavirus infections - the state of the art. Emerg Microbes Infect 2020; 9(1): 747-56.

25. Young S, Taylor SN, Cammarata CL, et al. Clinical Evaluation of BD Veritor SARS-CoV-2 Pointof-Care Test Performance Compared to PCR-Based Testing and versus the Sofia 2 SARS Antigen Point-of-Care Test. J Clin Microbiol 2020; 59(1).

26. Sullivan CB, Schwalje AT, Jensen M, et al. Cerebrospinal Fluid Leak After Nasal Swab Testing for Coronavirus Disease 2019. JAMA Otolaryngology-Head \& Neck Surgery 2020; 146(12): 1179-81.

27. Wölfel R, Corman VM, Guggemos W, et al. Virological assessment of hospitalized patients with COVID-2019. Nature 2020; 581(7809): 465-9.

28. Robert Koch-Institut: COVID-19-Dashboard, https://experience.arcgis.com/experience/478220a4c454480e823b17327b2bf1d4 (Accessed 4 March 2021).

29. Bayerisches Landesamt für Statistik: Die Gliederung der Bevölkerung nach Kreisen sowie nach Alter, Geschlecht und nach Deutschen und Ausländern, https://www.statistik.bayern.de/mam/produkte/veroffentlichungen/statistische berichte/a1300c 201800. xla (Accessed 17 February 2021).

30. Bayerisches Landesamt für Gesundheit und Lebensmittelsicherheit: Übersicht der Fallzahlen von Coronavirusinfektionen in Bayern, https://www.Igl.bayern.de/gesundheit/infektionsschutz/infektionskrankheiten a z/coronavirus/karte cor onavirus/ (Accessed 17 February 2021).

31. Centers for Disease Control and Prevention (CDC): Interim Guidelines for Collecting and Handling of Clinical Specimens for COVID-19 Testing, https://www.cdc.gov/coronavirus/2019ncov/lab/guidelines-clinical-specimens.html (Accessed 3 March 2021).

32. European Centre for Disease Prevention and Control (ECDC): Diagnostic testing and screening for SARS-CoV-2, www.ecdc.europa.eu/en/covid-19/latest-evidence/diagnostic-testing (Accessed 3 March 2021). 2020.

33. Bundesinstitut für Arzneimittel und Medizinprodukte: Antigen-Tests zum direkten Erregernachweis des Coronavirus SARS-CoV-2, https://antigentest.bfarm.de/ords/f?p=101:100:13556100388097:...::\&tz=1:00 (Accessed on 23 October 2020).

34. Vibholm LK, Nielsen SSF, Pahus MH, et al. SARS-CoV-2 persistence is associated with antigen-specific CD8 T-cell responses. EBioMedicine 2021; 64.

35. Brown L, Cai, T., \& DasGupta, A. . Interval Estimation for a Binomial Proportion, Statist. Sci, 16(2), 101-133; 2001.

36. Avadhanula V, Nicholson EG, Ferlic-Stark L, et al. Viral load of SARS-CoV-2 in adults during the first and second wave of COVID-19 pandemic in Houston, TX: the potential of the super-spreader. $J$ Infect Dis 2021.

37. Krone M, Noffz A, Richter E, Vogel U, Schwab M. Control of a COVID-19 outbreak in a nursing home by general screening and cohort isolation in Germany, March to May 2020. Eurosurveillance 2021; 26(1): 2001365.

38. Richard-Greenblatt M, Ziegler MJ, Bromberg V, et al. Impact of Nasopharyngeal Specimen Quality on SARS-CoV-2 Test Sensitivity. medRxiv 2020.

39. Galloway SE, Paul P, MacCannell DR, et al. Emergence of SARS-CoV-2 B.1.1.7 Lineage United States, December 29, 2020-January 12, 2021. MMWR Morb Mortal Wkly Rep 2021; 70(3): 95-9. 
medRxiv preprint doi: https://doi.org/10.1101/2021.03.27.21253966; this version posted March 29, 2021. The copyright holder for this preprint (which was not certified by peer review) is the author/funder, who has granted medRxiv a license to display the preprint in perpetuity.

It is made available under a CC-BY 4.0 International license .

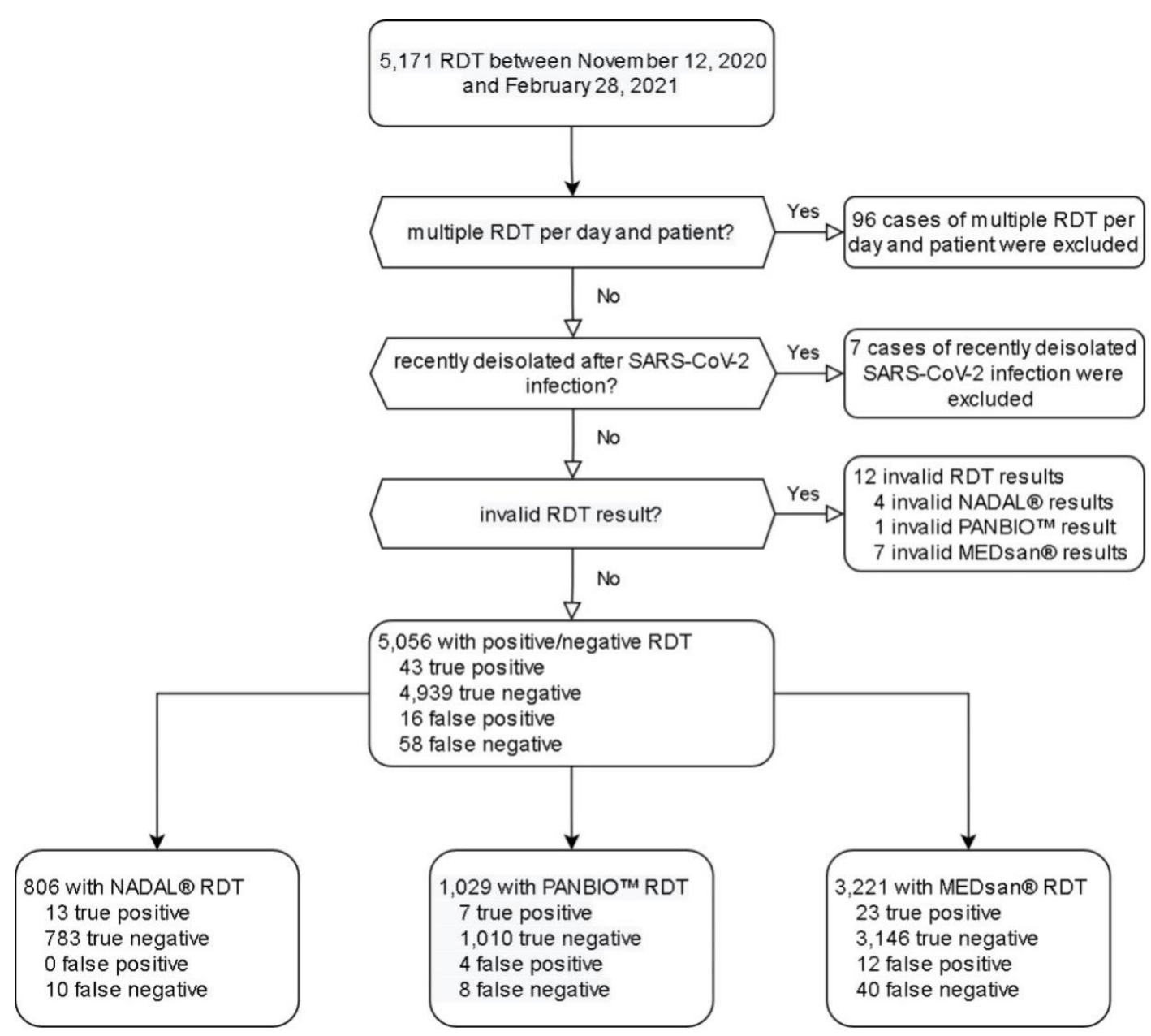

Fig. 1: Enrollment of antigen rapid diagnostic test results in the study

RDT: Antigen rapid diagnostic test

RT-qPCR: Quantitative reverse transcription polymerase chain reaction 
medRxiv preprint doi: https://doi.org/10.1101/2021.03.27.21253966; this version posted March 29, 2021. The copyright holder for this preprint (which was not certified by peer review) is the author/funder, who has granted medRxiv a license to display the preprint in perpetuity.

\section{It is made available under a CC-BY 4.0 International license.}

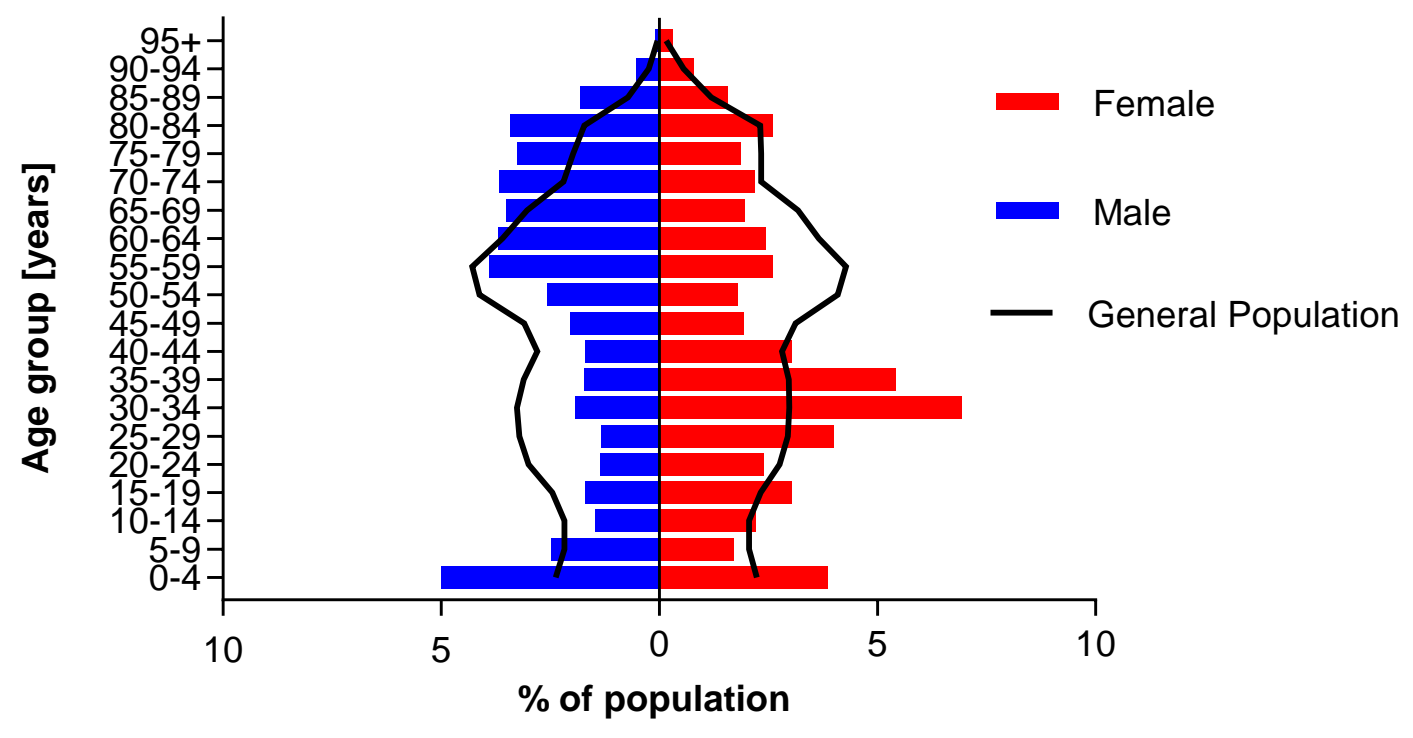

Fig. 2: Demographics of the study population compared to the general population of the hospital's catchment area

Study population (red and blue bars, $n=5,067$ ) was compared to the general population of the hospital's catchment area Lower Franconia (black line, $n=1,317,619$ ) as of December 31, 2019. Due to privacy reasons, one person with diverse gender was excluded from the figure. No data on population with diverse gender was available for Lower Franconia. Population data were obtained from Bavarian federal office for statistics ${ }^{29}$ 

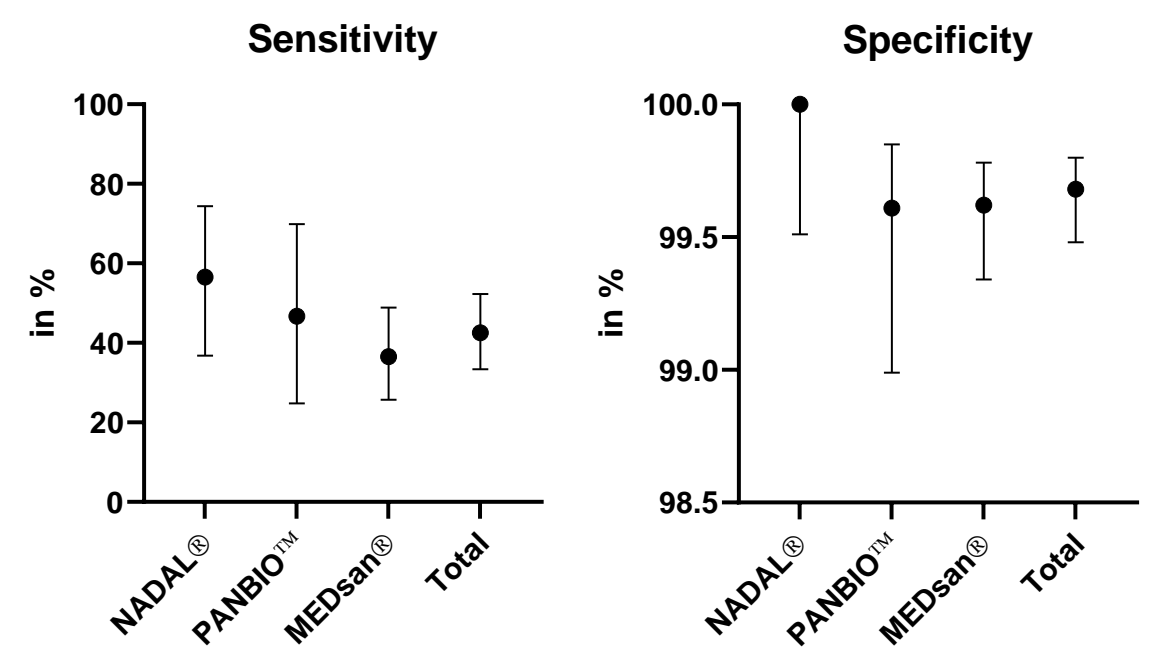

\section{Positive predictive value}

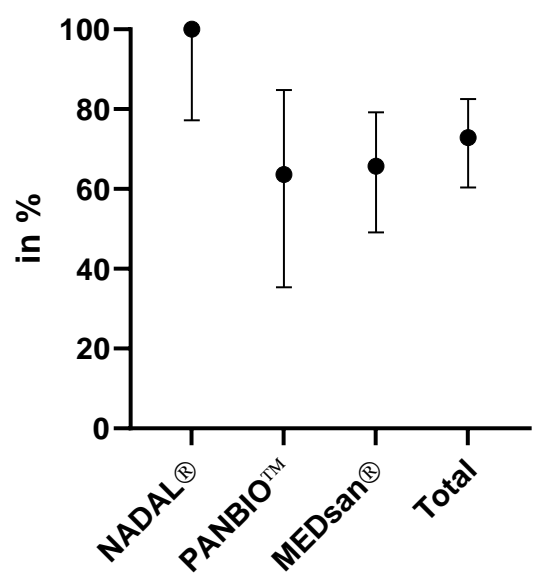

\section{Negative predictive value}

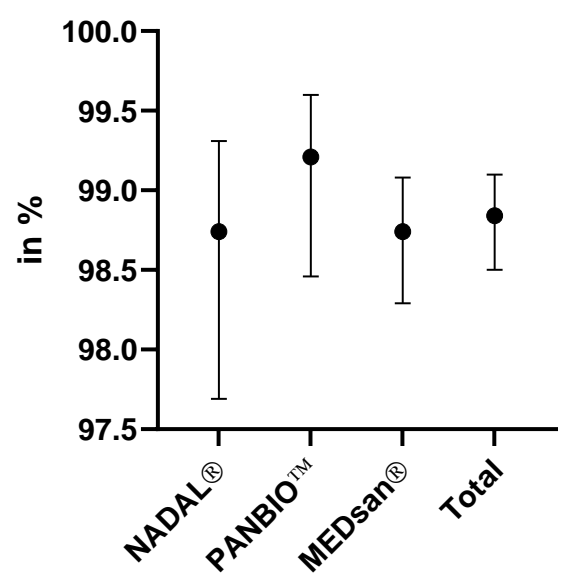

Fig. 3: Antigen rapid diagnostic test performance compared to quantitative reverse transcription polymerase chain reaction by manufacturer

Sensitivity, specificity, positive predictive value and negative predictive value of antigen rapid diagnostic tests from three manufacturers (nal von minden NADAL ${ }^{\circledR}$, Abbott PANBIO ${ }^{\mathrm{TM}}$, MEDsan ${ }^{\circledR}$ ) in comparison to quantitative reverse transcription polymerase chain reaction, $n=5,046$ 


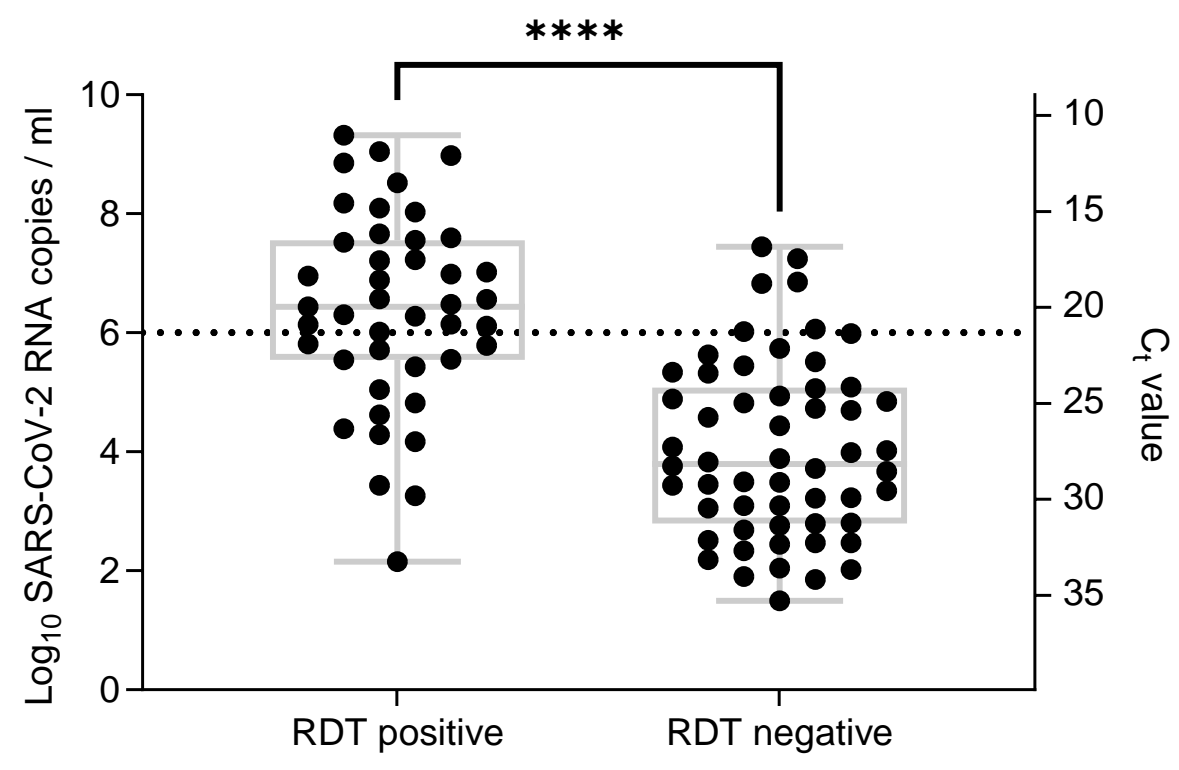

Fig. 4: Antigen rapid diagnostic test result in comparison to viral load

Viral load was determined by quantitative reverse transcription polymerase chain reaction (RT-qPCR, $n=99)$, dotted line: viral load of $10^{6}$ SARS-CoV-2 RNA copies per ml. Due to limited sample volume two samples could not be retested using the reference RT-qPCR method. ****: p<0.0001

RDT: Antigen rapid diagnostic test

$C_{t}$ : Cycle threshold 
medRxiv preprint doi: https://doi.org/10.1101/2021.03.27.21253966; this version posted March 29, 2021. The copyright holder for this preprint (which was not certified by peer review) is the author/funder, who has granted medRxiv a license to display the preprint in perpetuity.

It is made available under a CC-BY 4.0 International license .

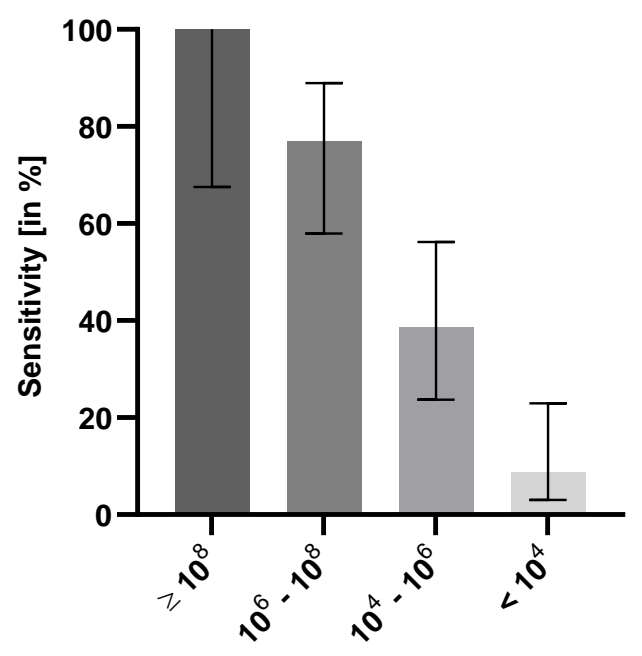

Viral load [SARS-CoV-2 RNA copies per ml]

Fig. 5: Sensitivity of antigen rapid diagnostic testing in relation to viral load

Viral load was determined by quantitative reverse transcription polymerase chain reaction $(n=99)$ 